ELWIRA WARDA* - LUBLIN

\title{
BRACTWA SZKAPLERZNE - DUCHOWE WSPÓLNOTY WIERNYCH
}

Bractwo szkaplerzne to erygowane kanonicznie i pozostające pod zwierzchnictwem ordynariusza zrzeszenie wiernych, którego celem było rozbudzenie życia chrześcijańskiego wśród członków poprzez m.in. rozszerzanie kultu Matki Bożej Szkaplerznej, szczególnie przez naśladowanie jej cnót i ćwiczenia duchowe. Zewnętrznym wyrazem przynależności do bractwa był tzw. mały szkaplerz składający się z dwóch małych kawałków poświęconego materiału połączonych tasiemką, noszonego na piersi i plecach. Przyjęcie do wspomnianego bractwa dokonuje się poprzez nałożenie szkaplerza sukiennego, który później zastępowano często noszonym na szyi medalikiem szkaplerznym ${ }^{1}$.

Początki bractw szkaplerznych sięgają XIII wieku, kiedy rozwinął się masowo kult Najświętszej Maryi Panny Szkaplerznej, propagowany przez zakony. Pierwsze tego typu bractwa powstały we Florencji, Bolonii, Wenecji oraz innych włoskich miastach. Poprzez bractwa szkaplerzne wierni mogli dostąpić udziału w zasługach i dobrych uczynkach oraz pobożnych ćwiczeniach danego zakonu.

\section{Bractwo Trójcy Przenajświętszej}

Szkaplerz Trójcy Przenajświętszej został objawiony św. Janowi z Mathy, kiedy podczas celebrowanej przez niego mszy św. na ołtarzu pojawił się anioł $\mathrm{w}$ białej szacie z krzyżem $\mathrm{w}$ kolorach czerwonym oraz niebieskim na piersiach i plecach, trzymający w skrzyżowanych rękach dwóch więźniów: chrześcijanina i Maura ${ }^{2}$. Wkrótce po założeniu zakonu w 1198 r. Jan de Matha ${ }^{3}$ utworzył Bractwo Przenajświętszej Trójcy, którego członkowie nosili mały szkaplerz trynitarzy z białej wełny z krzyżem czerwono-niebieskim. Formuła poświęcenia i nałożenia

* Elwira Warda - mgr filozofii, starszy bibliotekarz w Bibliotece Uniwersyteckiej KUL, e-mail: warda@kul.lublin.pl

${ }^{1}$ ABC chrześcijanina, Warszawa 1996, s. 251.

${ }^{2}$ Ann Ball, Katolickie sakramentalia, Gdańsk 2005, s. 176-177.

${ }^{3}$ Jan de Matha (1150-1213) - założyciel Zakonu Przenajświętszej Trójcy od Wykupu Niewolników. W roku 1198 papież Innocenty III wydał bullę, która aprobowała zakon i jego regułę. 
szkaplerza znajduje się w Rytuale Rzymskim: Benedictio et impositio scapularis Sanctissimae Trinitatis. Członkowie dawnego bractwa odmawiali trzy razy Ojcze nasz, Zdrowaś Maryjo i Chwała Ojcu na cześć Trójcy Świętej oraz Witaj Królowo jako prośbę o cierpliwość dla chrześcijańskich niewolników. Trynitarze odmawiali z wiernymi modlitwy w poniedziałki na cmentarzu o wyzwolenie dusz z Czyśćca. Członków bractwa szkaplerznego papieże obdarzali licznymi odpustami ${ }^{4}$. Aby z nich korzystać konieczne było przyjęcie i noszenie szkaplerza, wpisanie się do księgi bractwa i odmawianie codziennie ku czci Trójcy Przenajświętszej po trzy razy Ojcze nasz, Zdrowaś Maryjo i Chwała Ojcu. Każdy nowy szkaplerz powinien być poświęcony. Do bractwa Szkaplerza Trójcy Przenajświętszej mogli przyjmować tylko trynitarze oraz kapłani przez nich upoważnieni ${ }^{5}$. Obecnymi celami stowarzyszenia są: cześć i uwielbienie Trójcy Przenajświętszej, miłość bliźniego w duchu zakonu, działalność misyjna akcentująca głoszenie Chrystusa Wyzwoliciela, czczenie Maryi jako Patronki i Matki Bożej od Dobrego Wykupu oraz budowanie życia wspólnotowego inspirowanego tajemnicą jedności Trójcy. Prawdopodobnie pierwszą w dziejach wzmianką o bractwie była bulla Innocentego III Operante Patre luminum z dnia 2 czerwca 1209 roku.

\section{Bractwo Najświętszej Maryi Panny z Góry Karmel}

W nocy z 15/16 lipca 1251 roku w Aylesford w Anglii św. Szymonowi Stockowi objawiła się Matka Boska otoczona aniołami, która ukazała mu brązową szatę jako znak zbawienia, ratunek w niebezpieczeństwach oraz przywilej dla karmelitów ${ }^{6}$. Po tym wydarzeniu liczni wierni zaczęli nosić brązowy szkaplerz i ta duchowa przynależność do zakonu dała początek bractwu. W tzw. bulli sobotniej z 3 marca 1322 roku papież Jan XXII zatwierdził przywileje karmelitów, które potwierdził papież Klemens VII bullą Ex clementi z 12 sierpnia 1530 roku. Do Polski bractwo przybyło wraz z pierwszymi fundacjami klasztorów karmelitańskich w Krakowie (1397), Poznaniu (1400), Bydgoszczy (ok. 1400), Jaśle (1438) i Gdańsku (1462). Najstarszym na ziemiach polskich było bractwo szkaplerzne u karmelitów w Krakowie na Piasku. Dokumenty z XVII wieku opisują jego strukturę prawną i organizacyjną, zarząd, fundusze, przywileje, obowiązki i wykazy członków oraz zadania apostolskie. Decydującą rolę w rozwoju tego bractwa odegrał generał zakonu Jan Chrzciciel Rossi, który od papież Grzegorza XIII otrzymał szczegółowe ustalenia dotyczące tzw. przywileju sobotniego. W bulli Cum laudes z 18 października 1577 roku papież Grzegorz XIII potwierdził odpusty szkaplerzne nadane przez poprzedników? . Natomiast papież Paweł V w bulli Cum certas z 30 października 1606 roku udzielił przywileju generałowi karmelitów zakładania arcybractwa szkaplerznego nie tylko w kościołach karmelitańskich. Szkaplerz karmelitański nosili liczni wład-

${ }^{4}$ E. Warda, Szkaplerzne bractwa, w: Encyklopedia Katolicka (dalej: EK), t. 19, Lublin 2013, kol. 62.

${ }^{5}$ Ball, Katolickie sakramentalia, s. 177.

${ }^{6}$ B. J. Wanat, Zakon karmelitów bosych w Polsce, Kraków 1979, s. 30.

${ }^{7}$ „Głos Karmelu", 20 (1951) nr 7-8, ss. 172-177. Oryginał bulli sobotniej papieża Jana XXII zaginął. 
cy europejscy, a w Polsce niemal wszyscy królowie, począwszy od Jadwigi i Władysława Jagiełły, którzy zostali jego pierwszymi członkami. Struktura organizacyjna bractwa oparta była na normach konstytucji Klemensa VIII Quaecumque z 7 grudnia 1604 roku$^{8}$. W uroczystość Matki Bożej Szkaplerznej w dniu 16 lipca odbywały się wybory zarządu ${ }^{9}$. Prawo przyjmowania do bractwa mieli tylko karmelici lub kapłani do tego upoważnieni przez ich generałów i prowincjałów. Do bractwa można wstąpić i przyjąć szkaplerz, poświęcony według odpowiedniej formuły, w każdym klasztorze karmelitańskim lub kościele, przy którym bractwo zostało erygowane. Kto pragnie pełnego uczestnictwa w dobrach zakonu, musi wysłać swoje imię i nazwisko do klasztoru karmelitańskiego lub kościoła, przy którym działa bractwo celem wpisania do jego księgi. Najlepiej jednak dokonać tego osobiście i poprosić o wypowiedzenie formuły przyjęcia. Warunkami korzystania ze wszystkich dobrodziejstw jest przyjęcie szkaplerza z rąk uprawnionego kapłana, wpisanie do księgi bractwa, nieustanne noszenie na sobie szkaplerza, codzienne odmawianie naznaczonej modlitwy, zwykle Pod Twoja obrone, naśladowanie cnót MMP, szerzenie jej czci oraz trwanie w łasce uświęcającej ${ }^{10}$.

\section{Bractwo Matki Boskiej od Siedmiu Boleści}

Na Wschodzie kult Matki Boskiej Bolesnej w liturgii pojawił się w VII wie$\mathrm{ku}$, natomiast na Zachodzie początek oddawania Jej czci zbiega się z okresem wypraw krzyżowych. Zakon Sług Maryi (serwici) powstał z inicjatywy siedmiu zamożnych kupców zrzeszonych w Bractwie Maryjnym (Laudesi), którzy otrzymali wezwanie do przejścia na służbę Maryi. Kupcy ci w 1233 roku podczas modlitwy na zakończenie obchodów święta Wniebowzięcia ujrzeli Maryję, która obiecała opiekę i pomoc oraz nakazała im porzucić świeckie życie i całkowicie poświęcić się Bogu. W Wielki Piątek 1240 roku, podczas modlitwy, bracia ujrzeli Matkę Boską otoczoną olśniewającym światłem ubraną w długi czarny płaszcz i trzymającą $\mathrm{w}$ dłoniach czarny habit. Właśnie taki strój przyjęli zakonnicy wraz z nazwą Słudzy Maryi oraz regułą św. Augustyna ${ }^{11}$. Wkrótce po tym wydarzeniu papież Aleksander IV erygował Zakon Sług. Nowe zgromadzenie propagowało wśród wiernych Bractwo Szkaplerza Czarnego (konfratrzy nakładali czarne szkaplerze) utworzonego przy zakonie. Konfraternia popularyzowała nabożeństwo do Siedmiu Boleści Maryi ${ }^{12}$. Głównym celem noszenia szkaplerza jest rozważanie męki i boleści Najświętszej Maryi Panny.

Gdy pod koniec XV stulecia wzmógł się kult Matki Boskiej Bolesnej, pojawiło się wówczas określenie: Matka Boska od Siedmiu Boleści, a rozważane boleści to: Proroctwo Symeona, Ucieczka do Egiptu, Zgubienie Pana Jezusa w Jerozolimie, Spotkanie z Synem na Drodze Krzyżowej, Stanie pod Krzyżem, Trzymanie martwego Ciała Jezusa, Złożenie Go do grobu.

\footnotetext{
${ }^{8}$ Wanat, Zakon karmelitów bosych w Polsce, s. 723.

${ }^{9}$ J.W. Gogola, Szkaplerzna Matka Boża, w: EK, t. 19, Lublin 2013, kol. 59.

${ }^{10}$ B. Smyrak, Dar mojej Matki, Czerna-Poznań 2010, s. 77.

${ }^{11}$ Ball, Katolickie sakramentalia, s. 169.

${ }^{12}$ N. Lemaitre, M.T. Quinson, V. Sot, Stownik kultury chrześcijańskiej, Warszawa 1997, s. 278.
} 
Założycielem kolejnego bractwa Matki Boskiej od Siedmiu Boleści w 1490 roku we Flandrii był proboszcz Reimerswaal i Burges ks. Jan de Coudenberghe. Kanonicznej aprobaty bractwu niezwłocznie udzielił David de Bourgogne biskup Utrechtu, a papież Aleksander VI oficjalnie je zatwierdził 25 października 1495 roku. Kult Matki Boskiej od Siedmiu Boleści rozpowszechnił się we Francji, w Niemczech oraz Hiszpanii. Dnia 9 lipca 1667 roku Kongregacja Obrzędów wyraziła zgodę na obchodzenie święta patronalnego w zakonie serwitów w trzecią niedzielę września, natomiast papież Pius VII dekretem z 18 września 1814 roku rozszerzył obchody tego święta na cały Kościół ${ }^{13}$.

Szkaplerz Bractwa Od Siedmiu Boleści NMP składa się z dwóch prostokątnych płatków wełnianego sukna koloru czarnego, połączonych ze sobą dwoma sznurkami lub tasiemkami dowolnego koloru z dowolnymi ozdobami. Do bractwa mogą przyjmować tylko kapłani zakonu serwitów oraz z upoważnienia generała zakonu rektorzy tego bractwa, a obecnie w Polsce kustosz sanktuarium Matki Bożej Bolesnej w Limanowej. Formuła poświęcania, nakładania szkaplerza i przyjmowania do bractwa znajduje się w Rytuale Rzymskim: Benedictio et impositio Scapularis Nigri Septem Doplorum B. Marae Virg. Zapisywanie imion nowych członków do księgi bractwa jest obowiązkowe. Każde założone kanonicznie bractwo powinno mieć ołtarz lub kaplicę Siedmiu Boleści NMP. Członkowie mają zalecone rozmaite pobożne praktyki: noszenie czarnego szkaplerza, odmawianie w piątki Różańca do Siedmiu Boleści (o ile jest to możliwe w kaplicy bractwa), codzienne siedmiokrotne odmawianie Zdrowaś Maryjo na cześć Siedmiu Boleści lub rozważanie jednej z nich oraz dwukrotne uczestnictwo w ciągu roku w czuwaniach, przypadających w Adwent i Wielki Post. Każdego roku, zwykle 15 września, członkowie bractwa urządzają uroczystą procesję w święto Matki Boskiej Bolesnej ${ }^{14}$.

\section{Bractwo Niepokalanego Poczęcia NMP}

Szkaplerz Niepokalanego Poczęcia Najświętszej Maryi Panny początek bierze w Hiszpanii. W XV wieku w Toledo św. Beatrycze de Silva Meneses ${ }^{15}$ zało- $^{-}$ żyła Zakon Franciszkanek od Niepokalanego Poczęcia NMP (koncepcjonistek), zatwierdzony przez papież Juliusza II w roku $1511^{16}$. Jednym z wymogów reguły tego zakonu było noszenie pod białym habitem szkaplerza koloru niebieskiego ku czci Niepokalanego Poczęcia. Ludzie świeccy przyswoili sobie taką formę pobożności przyjmując szkaplerz, któremu na prośbę zakonnic Stolica Apostolska udzieliła specjalnych odpustów i przywilejów.

W dniu 2 lutego 1616 roku w Neapolu, w uroczystość Ofiarowania Pańskiego, założycielka Zakonu Sióstr Teatynek - Urszula Benincasa miała wizję Matki Bo-

${ }^{13}$ Julian Wojtkowski, Bolesna Matka Boża, w: EK, t. 2, Lublin 1989, s. 755.

${ }^{14}$ T. Szkopek, Szaty zbawienia, Gdańsk 2005, s. 157-180.

${ }^{15}$ Beatrycze z Silvy, właśc. Beatriz da Silva Meneses (1424-1492) - założyła oparte na regule św. Benedykta zgromadzenie Sióstr od Niepokalanego Poczęcia Najświętszej Maryi Panny (koncepcjonistki) w Galliana koło Toledo. Po jej śmierci koncepcjonistki zmieniły regułę benedyktyńską na franciszkańską.

${ }^{16}$ Szkopek, Szaty zbawienia, s. 157-180. 
żej trzymającej Dzieciątko Jezus, ubranej w białą szatę, na którą narzucona była wierzchnia szata niebieska ${ }^{17}$. Jezus rzekł:

Chcę, abyś założyła zakon panien pod wezwaniem Niepokalanego Poczęcia, które by nosiły suknie kształtu i koloru, jaki ma Matka moja, i obiecuję tym, którzy żyć będą według wskazanej reguły udzielać łask szczególnych i darów duchownych w obfitości.

Urszula poprosiła o takie same łaski dla osób świeckich, które nosiłyby wspomnianą szatę. Habit ów miał wyrażać cześć dla Niepokalanego Poczęcia, a w zamian za jego noszenie Chrystus obiecał specjalne łaski dla zakonu teatynek od Niepokalanego Poczęcia NMP. Dzieła rozpowszechniania szkaplerza Niepokalanego Poczęcia podjęli się teatyni. 30 stycznia 1671 roku papież Klemens X zaaprobował noszenie tego szkaplerza oraz nadał odpusty i przywileje, które ubogacali następni papieże. Odpusty zupełne obowiązują pod zwykłymi warunkami: w dniu przyjęcia szkaplerza, w uroczystości Niepokalanego Poczęcia NMP, Wniebowzięcia NMP, Narodzenia, Ofiarowania, Zmartwychwstania i Wniebowstąpienia Pańskiego, 7 sierpnia w dniu św. Kajetana (założyciela teatynów) oraz w momencie śmierci.

W 1894 roku powstało Bractwo Niepokalanego Poczęcia NMP i Matki Bożej przy kościele teatynów pw. św. Andrzeja z Valle w Rzymie, przekształcone później w arcybractwo. Jego członkowie nakładali szkaplerze błękitne ${ }^{18}$.

W Polsce wspomniany szkaplerz zaczął rozpowszechniać Stanisław Papczyński ${ }^{19}$ (1631-1701), który uzyskał od papież Innocentego XI - na mocy brewe z 20 marca 1681 roku - przywilej zakładania Bractw Niepokalanego Poczęcia NMP przy kościołach mariańskich, związanych z odmawianiem Koronki Dziesięciu Cnót Matki Boskiej ${ }^{20}$. Były to bractwa modlące się za dusze cierpiące w czyśćcu. W roku 1733 o. Kazimierz od św. Józefa Wyszyński² ${ }^{21}$ (1700-1755) zwrócił się do teatynów w Rzymie z prośbą o udzielenie upoważnienia do propagowania niebieskiego szkaplerza. Reformator zakonu marianów, bł. abp Jerzy Matulewicz, otrzymał podobne upoważnienie 1 grudnia 1911 roku, a o. Donald Petraitis, przełożony generalny marianów, 3 lipca 1992 roku uzyskał dla siebie i swoich następców wieczyste upoważnienie od generała teatynów do błogosławieństwa i nakładania szkaplerza Niepokalanego Poczęcia NMP. Z otrzymanym przywilejem związane jest również prawo do udzielania odpustu zupełnego wiernym, którzy nosili szkaplerz w momencie ich śmierci. Z czasem Bractwa Niepokalanego Poczęcia przy kościołach mariańskich nazywano bractwami szkaplerznymi. Za sprawą marianów bractwo i szkaplerz rozpowszechniają się nie tylko w Polsce,

${ }^{17}$ Ball, Katolickie sakramentalia, s. 167.

${ }^{18}$ Tamże, s. 168.

${ }^{19}$ Stanisław Papczyński, Stanisław od Jezusa i Maryi Papczyński (1631-1701) - założyciel Zgromadzenia Księży Marianów.

${ }^{20}$ Warda, Szkaplerzne bractwa, s. 61.

${ }^{21}$ Kazimierz Wyszyński (1700-1755) - marianin. W 1723 r. w Rzymie wstąpił do zakonu i po otrzymaniu białego habitu marianów wrócił do Polski. W roku 1726 przyjął święcenia kapłańskie. Założył pierwszy klasztor mariański w Balsamao (Portugalia). 
ale i na świecie - zwłaszcza w Stanach Zjednoczonych, za pośrednictwem Centrum Stowarzyszenia Pomocników Mariańskich w Stockbridge.

Pierwotnym celem bractwa związanego z teatynami było rozszerzanie czci Niepokalanej i modlitwa o nawrócenie grzeszników, bez szczególnych obowiązków. Obecnie dodaje się modlitwę za dusze w czyśćcu i do Miłosierdzia Bożego. Do bractwa szkaplerza Niepokalanego Poczęcia przyjmować mogą tylko teatyni i kapłani upoważnieni przez ich generała. Kościół do uzyskania łask ogólnych nie przepisał żadnych modlitw ani dobrych uczynków. Celem noszenia niebieskiego szkaplerza jest uczczenie Niepokalanego Poczęcia Najświętszej Maryi Panny, uznanie swojej grzeszności, modlitwa o naprawę złych obyczajów i nawrócenie grzeszników. Noszący ów szkaplerz ma udział we wszelkich dobrych uczynkach braci i sióstr Bractwa Szkaplerza Niepokalanego Poczęcia, prawo uzyskania licznych odpustów nadanych bractwu, szczególnie związanych z odwiedzeniem siedmiu rzymskich bazylik, kościoła Porcjunkuli w Asyżu, Ziemi Świętej i św. Jakuba w Compostelli. Do obowiązków konfratrów należy sześciokrotne odmawianie każdego dnia Ojcze nasz, Zdrowaś Maryjo i Chwała Ojcu na cześć Trójcy Przenajświętszej i Niepokalanego Poczęcia Panny Maryi w intencji wytępienia herezji, utwierdzenia pokoju i zgody między władcami chrześcijańskimi. Papież Pius IX ${ }^{22}$ zezwolił w dniu 3 grudnia 1847 roku, aby w miejscach, gdzie nie ma teatynów, wierni dla pozyskania odpustów mogli odwiedzać inne kościoły, mające ołtarz Najświętszej Maryi Panny.

Wierni noszący niebieski szkaplerz, a tym samym przynależący do Bractwa Niepokalanego Poczęcia mają udział we wszystkich dobrach duchowych teatynów oraz marianów nie tylko za życia, ale i po śmierci. Osoby te powinny zostać wpisane do księgi bractwa, która znajduje się w Centrum Stowarzyszenia Pomocników Mariańskich w Warszawie, a po wpisaniu do niej otrzymują specjalny dyplom poświadczający ten akt.

\section{Bractwo Matki Bożej Dobrej Rady}

Już od średniowiecza wierni wzywali pomocy zawartym w Litanii Loretańskiej wezwaniem do Maryi jako Matki Dobrej Rady, której najbardziej znany wizerunek znajduje się w Genazzano koło Rzymu. Nabożeństwo do Matki Bożej Dobrej Rady zaaprobował papież Paweł II, a kolejni papieże potwierdzili ją. W XVIII wieku papież Benedykt XIV ${ }^{23}$ ustanowił Bractwo Matki Bożej Dobrej Rady $^{24}$, a papież Leon XIII ${ }^{25}$ zatwierdził biały szkaplerz dekretem Kongregacji Obrzędów z dnia 21 grudnia 1893 roku i obdarzył go odpustami. W 1903 roku

${ }^{22}$ Pius IX, właśc. Giovanni Maria Mastai Ferretti (1792-1878) - papież od 16 czerwca 1846 r. do 7 lutego 1878 r. Był tercjarzem franciszkańskim.

${ }^{23}$ Benedykt XIV, właśc. Prospero Lorenzo Lambertini (1675-1758) - papież od 17 sierpnia 1740 r. do 3 maja 1758 r.

${ }^{24}$ Ball, Katolickie sakramentalia, s. 166.

${ }^{25}$ Leon XIII, właśc. Gioacchino Vincenzo Rapaelo Luigi Pecci (1810-1903) - papież od 28 lutego 1878 r. do 20 lipca 1903 r. Był tercjarzem franciszkańskim i troszczył się o rozwój tego zakonu. Uznaje się go za nowoczesnego papieża, który dąży do dialogu ze światem współczesnym, a jednocześnie nie rezygnuje $z$ ewangelizacji życia społecznego. 
wprowadził dodatkowe wezwanie do Litanii Loretańskiej. Członkowie tego bractwa noszą biały szkaplerz.

Celem nabożeństwa maryjnego jest prośba o dar rady, aby Maryja pomogła podjąć dobre decyzje, zarówno te wymagające rzetelnego rozważenia, jak i te, które musimy podjąć błyskawicznie, najczęściej w sytuacjach krytycznych. Celowi temu służy oddanie się pod Jej opiekę poprzez członkostwo w bractwie i noszenie szkaplerza. Władzę poświęcania i nakładania szkaplerza posiadają augustianie-eremici. Formuła tego ceremoniału znajduje się w Rytuale Rzymskim: Benedeictio et imposicio Scapularis B. Mariae V. De Bono Consilio. Szkaplerz ten nosić mogą wszyscy wierni, nawet ci, którzy nie należą do bractwa.

\section{Bractwo Św. Krzyża i Gorzkiej Męki Pana Jezusa (Męki Pańskiej)}

Wspólnotę poświęconą kultywowaniu pamięci o Męce Pana Jezusa założył św. Paweł od Krzyża ${ }^{26}$ w 1737 r. Habit zakonu pasjonistów był pierwowzorem dla małego czarnego szkaplerza męki. Noszący go uczestniczą we wszystkich duchowych łaskach i odpustach nadanych Bractwu Męki. Pierwotnie szkaplerz mogli nosić jedynie członkowie bractwa, jednakże w roku 1861 papież bł. Pius IX ${ }^{27}$ zaaprobował noszenie szkaplerza przez wiernych bez konieczności przynależenia do wspólnoty. Powinni jednak być oni wpisani do księgi szkaplerznej. Członkowie bractwa nie mają obowiązku nakładania szkaplerza, ale są do tego zachęcani.

Noszący ten szkaplerz związani są ze zgromadzeniem pasjonistów, uczestniczą w jego dobrach duchowych oraz zyskują wszystkie odpusty brackie. Nie mają jednak obowiązkowych praktyk. Oprócz noszenia szkaplerza zaleca się im rozpamiętywanie Męki Pańskiej. Modlitwami związanymi z bractwem i czarnym szkaplerzem Św. Krzyża i Męki Pana Naszego Jezusa Chrystusa były: Koronka do Pana Jezusa, Stopnie Męki i Godziny Męki oraz nabożeństwa do Matki Bożej Bolesnej. Obecnie bractwo, jak i sam szkaplerz niemalże zanikły.

Upoważnienie do poświęcania i nakładania tego szkaplerza (formuła znajduje się w Rytuale Rzymskim: Benedictio et impositio Scapularis Nigri ss. Crucis et Passionis D.N.J.C.) należy nadal do generała pasjonistów.

\section{Bractwo Matki Bożej Uzdrowienie Chorych}

W 1860 roku kamilianin, bł. Ferdynand Vicari założył Bractwo Matki Bożej Uzdrowienie Chorych, którego patronami są śś. Józef i Kamil ${ }^{28}$. Bractwo to podniesione zostało przez papieża bł. Piusa IX do godności arcybractwa.

Jego celem jest wypraszanie pomocy dla chorych, zwłaszcza konających. Członkowie odmawiają kamiliańską koronkę za konających i modlitwy za chorych, rozważają Pismo Święte i pomagają cierpiącym ludziom. Bractwo eryguje generał kamilianów, jednak może udzielić tych uprawnień innym kapłanom m.in. na poświęcenie czarnego szkaplerza z czerwonym krzyżem. Formuła poświęca-

${ }^{26}$ Paweł od Krzyża, właśc. Paolo Francesco Danei (1694-1775) - założyciel Zgromadzenia Pasjonistów. Regułę zakonną zgromadzenia zatwierdził Benedykt XIV 15 maja 1741 roku.

${ }^{27}$ Ball, Katolickie sakramentalia, s. 175.

${ }^{28}$ Tamże, s. 168-169. 
nia szkaplerza i przyjmowania do bractwa znajduje się w Rytuale Rzymskim: Benedictio et imposition Scapularis M. Mariae Virginis sub tit. Salus Infirmorum. Obecnie noszenie szkaplerza nie jest praktykowane, jednakże bractwo znów prowadzi działalność.

\section{Bractwo Matki Boskiej Milosierdzia}

Św. Piotr z Noli założył Zakon Maryi Panny od Wykupu Niewolników (mercedariusze $)^{29} \mathrm{~W} 1203 \mathrm{r}$. Zakon prowadził wszechstronną działalność: organizował szpitale, leprozoria, kliniki, sanatoria, kolegia i misje. Wierni zrzeszali się w bractwa, aby wesprzeć działalność zakonu modlitwą oraz pomocą materialną.

Obecnie celem bractwa, oprócz czci oddawanej NMP, jest troska o zbawienie dusz. Ze wstąpieniem do bractwa łączy się zawsze przyjęcie białego szkaplerza, na którego przedniej stronie umieszczony jest wizerunek Matki Boskiej Miłosierdzia, na odwrocie zaś symbole zakonu mercedariuszy. Prawo zakładania bractwa, poświęcania i nakładania wiernym szkaplerza posiada generał Zakonu Najświętszej Maryi Panny Miłosierdzia od Wykupu Jeńców. Formuła tej celebry znajduje się w Rytuale Rzymskim: Benedictio et impositio Scapularis B. Mariae Virg. De Mercede. Nazwiska przyjętych członków należy wpisać do księgi bractwa. Jego członkowie uczestniczą w procesjach, nabożeństwach i zebraniach brackich, odmawiają codziennie po trzy razy Ojcze nasz i Zdrowaś Maryjo lub Wierze na uproszenie cierpliwości dla niewolników chrześcijańskich oraz pełnią uczynki miłosierdzia, np. udzielanie noclegów ubogim, pielgrzymom, uwolnionym więźniom, naprowadzanie zbłąkanych na dobrą drogę, przywracanie zgody między powaśnionymi czy odmawianie modlitw za zmarłych członków bractwa.

\section{Bractwo Przenajdroższej Krwi Naszego Pana Jezusa Chrystusa}

W dniu 8 grudnia 1808 roku Franciszek Albertini powołał do życia Bractwo Przenajdroższej Krwi Naszego Pana Jezusa Chrystusa, którego celem był kult Krwi Chrystusa oraz pełnienie dzieł miłosierdzia wobec ludzi biednych i zagubionych, np. dotkniętych niewiarą, alkoholizmem itp. Bractwo od początku dawało wsparcie Zgromadzeniu Misjonarzy Krwi Chrystusa ${ }^{30}$.

\section{Bractwo Świętego Benedykta}

Życie zakonne we wspólnocie z praktyką noszenia szkaplerza zapoczątkował św. Benedykt z Nursji ${ }^{31}$. W średniowieczu mniejszy od zakonnego szkaplerz, który był miniaturą szkaplerza zakonnego, nakładano oblatom benedyktyńskim, czyli ludziom świeckim żyjącym według ducha zakonu benedyktynów. Mały szkaplerz zaczęli nosić, początkowo pod paskiem, członkowie bractwa św. Benedykta,

${ }^{29}$ Tamże, s. 167.

${ }^{30}$ Tamże, s. 172.

${ }^{31}$ Benedykt z Nursji (ok. 480-547) - ojciec monastycyzmu zachodniego, który w 529 r. założył klasztor na Monte Cassino, autor reguły benedyktyńskiej. Oryginał napisanej przez niego Reguły spłonął w 896 r. czasie pożaru klasztoru w Teano. Dewiza św. Benedykta to Ora et labora (łac. módl się i pracuj), a hasłem przewodnim reguły zakonu benedyktynów Ordo et pax (Lad i pokój). 
a przeznaczony był dla osób, które nie mogły sprostać wymogom oblackim. Ich obowiązkiem było noszenie szkaplerza, odprawianie przed snem rachunku sumienia i odmawianie trzykrotnie Ojcze Nasz, Zdrowaś Maryjo i Wierze w intencji rozwoju Kościoła. Przyjęcie do bractwa odbywa się przez nałożenie poświęconego szkaplerza i zapisanie do księgi. Szkaplerz św. Benedykta został oficjalnie zatwierdzony w 1869 roku, a uznany powszechnie w roku 1893. Prawo zakładania bractwa posiadają wszystkie klasztory benedyktyńskie należące do kongregacji w Cassino i Subiaco. W roku 1950 Stolica Apostolska zezwoliła oblatom św. Benedykta na noszenie medalika zamiast szkaplerza. Obecnie zwyczaj noszenia szkaplerza przez wiernych właściwie zanikł ${ }^{32}$.

\section{Bractwo Świętego Michala Archanioła}

W 1878 roku w kościele św. Eustachego w Rzymie powstało Bractwo Świętego Michała Archanioła, które rok później zostało przeniesione do kościoła św. Michała Archanioła w Pescherii (Rzym). W 1880 roku papież Leon XIII podniósł je do godności arcybractwa z prawem przyłączania innych bractw tego samego tytułu i udzielania im odpustów. Do udziału w dobrach duchowych związanych $\mathrm{z}$ bractwem wystarcza być do niego przyjętym, bez potrzeby noszenia szkaplerza ${ }^{33}$.

słowa kluczowe: szkaplerz, bractwa szkaplerzne, stowarzyszenia religijne, XIII wiek, Włochy

\section{BIBLIOGRAFIA}

ABC chrześcijanina, Warszawa 1996.

Ball Ann, Katolickie sakramentalia czyli jak czerpać z bogactw Kościoła, Gdańsk 2005. Bomba Władysław, Dary nieba, Kraków 2006.

Kuźmak Krystyna, Bractwo kościelne, w: Encyklopedia Katolicka t. 2, Lublin 1989.

Warda Elwira, Szkaplerzne bractwa, w: Encyklopedia Katolicka t. 19, Lublin 2013.

S. Ch., Bractwo, w: Encyklopedia kościelna, t. 1, Warszawa 1875.

Gozier André, Szkaplerz Najświętszej Maryi Panny z Góry Karmel: cenna poręka zbawienia, Warszawa 2014.

Kucharski Bartłomiej J., Szata Maryi, Kraków 2009.

Lemaitre Nicole, Quinson Marie-Thérèse, Sot Véronique, Słownik kultury chrześcijańskiej, Warszawa 1997.

M. B., szkaplerz, w: Podręczna Encyklopedia Kościelna, t. 37-38, Warszawa 1913.

O. Al., Bractwo Szkaplerzne, „Głos Karmelu”, 11 (1928).

O. Konstanty, O Bractwie Szkaplerznem, „Głos Karmelu”, 1(1930).

Philippe de Jésus-Marie, Szkaplerz: życie na wzór Maryi, Kraków 2013.

Pawłowska Iwona, Szkaplerz naszej Matki, Kraków 2011.

Smyrak Bernard, Dar mojej Matki, Warszawa 2010.

\footnotetext{
${ }^{32}$ Ball, Katolickie sakramentalia, s. 177.
}

${ }^{33}$ Tamże, s. 179. 
Św. Szymon Stock i pobożność szkaplerzna, Poznań 2014.

Szkopek Tomasz, Szaty zbawienia, Gdańsk 2005.

Szpiller Piotr, Zań-Ograbek Genowefa, Arcybractwo Szkaplerza Świętego przy kościele Karmelitów w Krakowie „Na Piasku ${ }^{\text {ee }}$ historia, duchowość, ikonografia, Kraków 2001.

Tochmański Włodzimierz, 300 lat patronatu św. Józefa nad Krakowem, Poznań 2015.

Wanat Benignus Józef, Zakon Karmelitów Bosych w Polsce, Kraków 1979.

Warda Elwira, Szkaplerzne bractwa, w: Encyklopedia Katolicka t. 19, Lublin 2013.

Zawada Marian, Tren królewskiej szaty, Kraków 2000.

\title{
SCAPULAR BROTHERHOODS \\ - SPIRITUAL COMMUNITIES OF THE FAITHFUL
}

\begin{abstract}
Summary
Scapular brotherhoods are religious associations, whose members are obliged to wear a "small" scapular of a specific style and colour, expressing the relationship with the spirituality of the religious order, with which the brotherhood is linked. The origins of scapular brotherhoods date back to the 13th century, and the first ones were established in Florence, Bologna, Venice and other Italian towns. Scapular brotherhoods include: the Brotherhood of the Holy Trinity, the Brotherhood of Our Lady of Mount Carmel, the Brotherhood of Our Lady of Sorrows, the Brotherhood of the Immaculate Conception, the Brotherhood of Our Lady of Good Counsel, the Brotherhood of St. Cross and Bitter Passion of the Lord Jesus, the Brotherhood of Our Lady of Health of the Sick, the Brotherhood of Our Lady of Charity, the Brotherhood of the Precious Blood of Our Lord Jesus Christ, the Brotherhood of St. Benedict and the Brotherhood of St. Michael the Archangel.
\end{abstract}

Keywords: scapular, scapular brotherhoods, religious associations, 13th century, Italy 